ISSN:2656-4270 (Online) 1410-4466 (Print) Accredited by Ministry of Research, Technology, and Higher Education with the ranking of Sinta (S4) SK NO.28/E/KPT/2019, 26th September 2019
Buletin Penelitian Sosial Ekonomi Pertanian Fakultas Pertanian Universitas Haluoleo

2021:23(1):21-26

http://ojs.uho.ac.id/index.php/sosek

doi: http://dx.doi.org/10.37149/sosek.v23i1.16734

\title{
ANALYSIS OF FOOD SECURITY LEVEL OF URBAN AND RURAL HOUSEHOLDS IN EAST JAVA PROVINCE
}

\author{
Puryantoro $^{\left.1^{*}\right)}$, Hasbiadi ${ }^{1)}$ \\ ${ }^{1}$ Faculty of Agriculture, Abdurachman Saleh University Situbondo East Java \\ ${ }^{2}$ Faculty of Agriculture, Sembilanbelas November University Kolaka Southeast Sulawesi \\ *Corresponding author: puryantoro@unars.ac.id
}

To cite this article:

Puryantoro, P., \& Hasbiadi, H. (2021). Analysis of Food Security Level of Urban and Rural Households in East Java Province. Buletin Penelitian Sosial Ekonomi Pertanian Fakultas Pertanian Universitas Haluoleo, $23(1), 21$. 26. doi:http://dx.doi.org/10.37149/bpsosek.v23i1.16734

Received: February 22, 2021; Accepted: April 29, 2021; Published: April 30, 2021

\begin{abstract}
Food security is an issue that continues to roll because it is closely related to people's welfare. Not only urban but rural residents have also been targeted in various strategies to meet pagan needs. This study aimed to analyze household food security in both urban and rural areas in East Java. Data collection uses Susenas secondary data for 2016-2019 issued by BPS East Java. The share of food expenditure analyzes the data. The analysis results show that the population in East Java, both in urban and rural areas, is at the level of food security status because the share value of food expenditure is less than $60 \%$. The share of urban food expenditure is lower than the share of rural food expenditure.
\end{abstract}

Keywords: food expenditure share; food security; urban; rural

\section{INTRODUCTION}

Food is a human need, and it is the right of every human being to fulfill his food needs. Efforts to meet food needs are needed to be achieved, one of which is realizing food security. The fulfillment of food for the state and individuals can be seen from the availability of sufficient food, starting from the quantity and quality, safe, diverse, nutritious, equitable, and affordable and does not conflict with religion, belief, and community culture, so that they can live healthy, active and productive in a sustainable manner. Of course, food security is not only the responsibility of the government but also the community. Food availability is a significant indicator of community welfare because it has an impact on solid economic development. So that food security is something that must be realized. According to (Wahyuni \& Fauzi, 2018), food security is closely related to poverty because the poor will find it challenging to meet their daily needs. This is because poverty is when a person or group of people, men, and women, cannot fulfill their fundamental rights to maintain and develop a dignified life.

Widayaningsih (2012) said problems regarding food security do not only occur in rural areas, in urban areas also experience many difficulties. Many residents urbanize in the hope of improving their level of welfare. The urban village criteria 2000 based on the Central Statistics Agency (2010) uses 3 (three) indicators as a measure, namely: population density per km2 (KPD), percentage of agricultural households (PRT), and the presence or access to urban facilities (AFU). Based on the 3 (three) indicators above, it is known that a village can achieve a maximum score of 26 and a minimum score of 2. While the cut of point used to determine urban villages is 10 . Those with a total score of 10 or more are designated as urban villages, whereas villages with less than ten are designated as rural villages.

Arida, Sofyan, \& Keumala (2015) said that food expenditure in poor households would be greater than non-food expenditure. This will affect the fulfillment of nutrition in determining household food security. The completion of nutrition obtained from the food consumed will determine the level of consumption. The higher the nutritional value of food in the form of energy consumed, the higher the energy consumption level. The same is true for protein consumption. 
The Central Statistics Agency (BPS) of East Java recorded that in March 2020, the number of poor people in East Java was recorded at 4,419.10 thousand people. This increased by 363.1 thousand people compared to September 2019, recorded at 4,056.00 thousand. The increase in the poor by $0.89 \%$ was caused by several factors, namely in September 2019-March 2020, there was general inflation of $1.36 \%$. Then, from September 2019 - March 2020, several food commodities experienced changes in the consumer price index (CPI), namely shallots increased by 50.64 percent, garlic increased by 48.62 percent. Then the increase in the index also occurred in red chili commodities (28.63 percent), granulated sugar (17.25 percent), broiler eggs (16.62 percent), chicken meat (3.84 percent), and cooking oil (3,62 percent). (Kominfo, 2020a)

Based on data (Kominfo, 2020b), the role of food commodities on the Poverty Line is much more significant than non-food things. The contribution of the Food Poverty Line to the Poverty Line in March 2020 was recorded at 74.97 percent, a slight increase compared to September 2019, which was 74.91 percent. Based on food commodities, several commodities that significantly contribute to poverty in rural and urban areas are rice, filtered kretek cigarettes, broiler eggs, granulated sugar, chicken meat, tempeh, and tofu instant noodles, coffee. And onions.

The condition of a country that has guaranteed security does not always reflect household food security. Household food security is an indicator of the formation of regional food security either in the region or region. Meanwhile, household food (food and non-food) expenditure is an indicator of household food security. The greater the share of a household's food expenditure, the lower the household's food security. According to Sinaga, Lubis, \& Darus (2017), a household's food security can be seen as an indicator of the share of household expenditure, both from food and non-food expenditures.

The share of food expenditure deserves to be used as an indicator of food security because it has a close relationship with various measures of food security, namely the level of consumption, food diversity, and income, and has characteristics that can be measured by numbers, simple enough to obtain and interpret, objective, and responsive to changes. due to changes in economic conditions, policies, and development programs. (Ilham \& Sinaga, 2007)

Previous research has researched food security status, such as the distribution of households according to the level of food security in Central Java. Food by 31.67 percent. (Purwaningsih, Hartono, \& Handoyo Mulyo, 2010). Meanwhile, Purwaningsih (2008) stated that North Sulawesi's food security is classified as guaranteed food security, but it is still found that households classified as food insecure are pretty high. The proportion of expenditure on food-insecure families in rural areas is relatively higher than that of urban residents. In general, the primary source of livelihood for foodinsecure households is in the agricultural sector. However, research on the level of food security status in East Java has not found many studies on the quality of food security in East Java. The difference with previous research is that it was conducted in different areas. Thus, this study aimed to compare household food security in rural and urban areas in East Java. The research implication is to provide a general description of food security in East Java to be used as a reference in formulating strategies and policies for food.

\section{MATERIALS AND METHODS}

The research method used to analyze the level of food security against food insecurity uses the secondary data analysis method. Secondary data analysis methods consist of secondary data collection methods, data processing methods, and data analysis methods. The data was obtained from the National Socio-Economic Survey (Susenas) conducted by BPS from 2016-2019. Data were analyzed using Food Expenditure Share, using the following equation (Indira Putri et al., 2019)

Food Expenditure Share $(\%)=\frac{\text { Expenditure for food needs (IDR/year) }}{\text { Total Household Expenditure (IDR/year) }}$

The analysis of the share of food expenditure is based on the method (Maxwell, 2000) by distinguishing two categories:

a. If the share of food expenditure is less than $60 \%$, the household is categorized as food insecure;

b. If the percentage of food expenditure is greater than or equal to $60 \%$, the household is food insecurity.

\section{RESULTS AND DISCUSSION}

The household consumption structure in East Java in 2019 was not much different from the consumption structure in the previous few years. Since 2014 the structure has begun to develop. Most household expenditures are no longer used for food consumption only. Still, they have started to 
shift to spending for non-food consumption such as clothing, housing, communication, health, education, technology, and so on. East Java residents who prioritized food consumption are now switching to non-food (BPS East Java, 2019). Food expenditure is highly dependent on the number of family members, household income, and the intensity and pattern of eating. Generally, household expenditure consists of two groups, namely food, and non-food spending.

Table 1. Average monthly food and non-food expenditures in urban areas in East Java, 2016-2019

\begin{tabular}{lrrrr}
\hline \multirow{2}{*}{ Spending } & \multicolumn{4}{c}{ Year } \\
\cline { 2 - 5 } & \multicolumn{1}{c}{2016} & \multicolumn{1}{c}{2017} & \multicolumn{1}{c}{2019} \\
\hline Food Expenditure & 487.168 & 532.127 & 562.768 & 554.493 \\
Food material & 266.458 & 282.963 & 291.400 & 276.227 \\
Prepared Food \& Drink & 164.581 & 196.369 & 216.526 & 219.486 \\
Cigarettes & 56.129 & 52.795 & 54.842 & 58.780 \\
Non-Food Expenditure & 587.523 & 613.461 & 650.784 & 675.010 \\
Expenditure Amount & 1.074 .691 & 1.145 .588 & 1.213 .552 & 1.229 .503 \\
\hline
\end{tabular}

Source: BPS Jawa Timur, 2017-2019

Expenditures for urban residents in East Java based on the data in Table 1 have increased every year. The phenomenon that occurs is that non-food spending is higher than food expenditure. Food expenditures for the urban population of East Java in 2017 increased by $4.4 \%$ from the previous year (BPS East Java, 2017). In 2018, there was only an increase of $2.8 \%$. Even in 2019, there was a decrease in the expenditure of $-0.7 \%$ from the previous year.

On the other hand, non-food spending has increased every year. In 2017 it was up 2.1\%. In 2018 it was up $2.9 \%$, and in 2019 it was up $1.8 \%$ from the previous year.

The most significant proportion of expenditure in 2016 was in urban areas in the non-food group at 54.67 percent, followed by spending for the food group at 45.33 percent. In 2017 the proportion of food expenditure reached $46.45 \%$, non-food expenditure was $53.55 \%$, and in 2018 it was $46.37 \%$ for food expenditure and $53.62 \%$ for non-food expenditure (BPS East Java, 2018). Meanwhile, for 2019 it is still the same as in previous years. Non-food expenditure occupies the highest proportion of $54.90 \%$ and $45.10 \%$ for food expenditure. (BPS East Java, 2019)

Lifestyle, the times, and accessibility of information and technology make urban residents spend more on non-food consumption than food consumption (BPS East Java, 2019). Based on Susenas data, urban residents in East Java spend more on non-food consumption such as housing and household facilities, various goods and services, clothing, footwear and headgear, durable goods, taxes, levies, and insurance party necessities. And ceremonies. This indicates that the level of welfare in the city is better, according to Ernst Engel's theory, which says that the proportion of consumer spending on non-food products is higher than the proportion of the expenditure on food.

Table 2. Share of food expenditure of urban area population in East Java, 2016-2019

$\begin{array}{ccc}\text { Year } & \text { Food Expenditure Share }(\%) & \text { Food Security Level } \\ 2016 & 45,33 & \text { Food Security } \\ 2017 & 46,45 & \text { Food Security } \\ 2018 & 46,37 & \text { Food Security } \\ 2019 & 45,09 & \text { Food Security }\end{array}$

Source: Processed secondary data, 2021

Residents of urban areas in East Java during the 2016-2019 period were in the food security category. It can be seen in table 2 that the share of food expenditure for four years is less than 60 , which means that urban communities in East Java have been able to meet their food needs well and have begun to allocate their expenditures to meet the needs of various non-food needs. The income of urban people can be said to be relatively high. According to Purwaningsih, Hartono, Masyhuri, \& Mulyo (2010), the higher the household income, the higher the purchasing power, and the easier it is for households to access food. Family income and expenses have a close relationship with food security status (Sari, Andrias, Bulak, \& Bulak, 2013)

Food and non-food expenditures for residents of rural areas in East Java for the 2016-2019 period can be seen in Table 3. Food and non-food expenditures for rural residents in East Java during the 2016-2019 period increased from the previous year. In 2017 food expenditure increased by $6.32 \%$ of the prior year, and non-food spending decreased by $0.02 \%$. In 2018 non-food expenditure experienced a higher increase than the previous year, namely $5.71 \%$, and food cost increased but 
was lower than the last year at $2.03 \%$. Meanwhile, in 2019 food expenditure only rose $0.77 \%$ from the previous year and rose $4.10 \%$ for non-food costs.

Table 3. Average monthly food and non-food expenditures in rural areas in East Java, 2016-2019

\begin{tabular}{lrrrr}
\hline \multirow{2}{*}{\multicolumn{1}{c}{ Spending }} & \multicolumn{4}{c}{ Year } \\
\cline { 2 - 5 } & \multicolumn{1}{c}{2016} & \multicolumn{1}{c}{2017} & 2018 & 2019 \\
\hline Food Expenditure & 369.548 & 419.400 & 436.818 & 443.597 \\
Food material & 219.140 & 241.453 & 244.600 & 241.247 \\
Prepared Food \& Drink & 92.885 & 122.338 & 138.153 & 143.370 \\
Cigarettes & 57.523 & 55.609 & 54.065 & 58.980 \\
Non-Food Expenditure & 304.534 & 304.399 & 341.263 & 370.428 \\
Expenditure Amount & 674.082 & 723.799 & 77.8081 & 814.025 \\
\hline
\end{tabular}

Source: BPS Jawa Timur, 2017-2019

The expenditure of the rural population is more dominant for food expenditure. In 2016, the proportion for food expenditure reached $54.82 \%$, and non-food expenditure was $45.18 \%$. The year 2018 was also still dominated by food expenditure which gained $57.94 \%$ and $42.06 \%$ for non-food expenditure. Meanwhile, in 2018 it reached $56.14 \%$ for food expenditure and $43.86 \%$ for non-food expenditure. The highest proportion in 2019 was still for food expenditure at $54.50 \%$ and non-food expenditure at $45.50 \%$.

Based on Table 4 from the analysis, it can be seen that the food status of the population in rural areas is at the food security level because the share value of food expenditure is less than $60 \%$. Even though it is below $60 \%$, compared to the level of food security in urban areas, it is still lower than in rural areas because the share of food expenditure is close to $60 \%$. The amount of food expenditure is because rural communities prefer to spend their income on food purchases. This is in line with Sinaga, Lubis, \& Darus (2017b). In a condition of limited income, food needs are prioritized so that in low-income groups, it will be seen that most of their income is used to buy food. However, Puryantoro \& Mayangsari (2020) research says that one of the high expenditures of rural communities in Situbondo is the increased consumption of cigarettes, which reaches $26.45 \%$ per month. Meanwhile, according to Martianto, Riyadi, \& Ariefian (2011), Food security affects nutritional status, so it is necessary to promote food self-sufficiency, especially in poor households in rural areas. Various factors cause the low income of rural people. Narrow job opportunities make sources of income also limited. Based on these findings, community empowerment programs such as providing job opportunities in rural areas are a priority to be able to increase revenue so that it will be in line with growing purchasing power because, according to Sari et al. (2013), there is no relationship between food security and education, employment, family size, asset ownership, knowledge, physical access, economic access, and food availability.

Table 4. Share of food expenditure for rural areas in East Java, 2016-2019

$\begin{array}{ccc}\text { Year } & \text { Food Expenditure Share } & \text { Food Security Level } \\ 2016 & 54,82 \% & \text { Food Security } \\ 2017 & 57,94 \% & \text { Food Security } \\ 2018 & 56,14 \% & \text { Food Security } \\ 2019 & 54,50 \% & \text { Food Security }\end{array}$

Source: Processed secondary data, 2021

From 2016 to 2019, the overall expenditure of the population of East Java has increased every year. The increase in spending can be an indication of the improving welfare achieved in East Java. According to Yuliana, Zakaria, \& Adawiyah (2013), the higher household expenditure, the higher the level of food security. In total spending for non-food needs between urban and rural areas, the difference is very significant. Spending in urban areas is double that in rural areas. This reflects the welfare of the population in urban areas to be better when compared to those in rural areas. Meanwhile, Ariani (2014) in Sugiarto, Karyani, \& Rochdiani (2019) an increase in the share of food expenditure does not mean that welfare has decreased. It is suspected that, on the contrary, the interest of the household has improved.

The share of food expenditure between urban and rural areas in East Java-based Table 2 and Table 4. There is a significant difference even though with the same status, namely food security, because it is less than $60 \%$. The share of urban food expenditure is lower than that of rural areas. 
Mulyo, Sugiyarto, \& Widada (2015) said that the percentage of low food expenditure means that they can meet their food needs well and start allocating their spending to meet various non-food needs.

\section{CONCLUSION}

The level of food security for urban and rural residents from 2016-2019 in East Java is in a food security condition because the share of food expenditure is less than $60 \%$. However, there is a difference in the value of food security between urban and rural areas. Urban areas have a lower share of food expenditure than rural areas. Urban residents consume more non-food than food consumption. On the other hand, rural residents have a higher consumption of food expenditure compared to non-food consumption.

\section{REFERENCES}

Arida, A., Sofyan, S., \& Keumala, F. (2015). Analisis Ketahanan Pangan Rumah Tangga Berdasarkan Proporsi Pengeluaran Pangan Dan Konsumsi Energi (Studi Kasus Pada Rumah Tangga Petani Peserta Program Desa Mandiri Pangan Di Kecamatan Indrapuri Kabupaten Aceh Besar). In Agrisep (Vol. 16). Retrieved from http://www.jurnal.unsyiah.ac.id/agrisep/article/view/3028

Badan Pusat Statistik. (2010). Peraturan Kepala Badan Pusat Statistik Nomor 37 Tahun 2010. In upload.wikimedia.org. https://upload.wikimedia.org/wikisource/id/d/d0/MFD_2010_Buku_3.pdf

BPS Jawa Timur. (2017). Statistik Pengeluaran untuk Konsumsi Rumah Tangga Provinsi Jawa Timur 2017. In BPS Provinsi Jawa Timur. BPS Provinsi Jawa Timur.

BPS Jawa Timur. (2018). Statistik Pengeluaran untuk Konsumsi Rumah Tangga Provinsi Jawa Timur 2018. In BPS Provinsi Jawa Timur. BPS Jawa Timur.

BPS Jawa Timur. (2019). Statistik Pengeluaran untuk Konsumsi Rumah Tangga Provinsi Jawa Timur 2019. In BPS Provinsi Jawa Timur.

llham, N., \& Sinaga, B. M. (2007). Penggunaan pangsa pengeluaran pangan sebagai indikator komposit ketahanan pangan. SOCA: Jurnal Sosial Ekonomi Pertanian, 7(3). Retrieved from https://ocs.unud.ac.id/index.php/soca/article/view/4217

Indira Putri, K., Murniati, K., Adawiyah Jurusan Agribisnis, R., Pertanian, F., Lampung, U., \& Soemantri Brojonegoro No, J. (2019). Pola konsumsi dan tingkat ketahanan pangan rumah tangga petani ubi kayu di Kecamatan Terusan Nunyai Kabupaten Lampung Tengah. In JIIA (Vol. 7). Retrieved from http://jurnal.fp.unila.ac.id/index.php/JIA/article/view/3778

Kominfo. (2020a). Maret 2020, BPS Jatim Catat Penduduk Miskin di Jatim 4.419,10 Ribu Jiwa. Dinas Komunikasi Dan Informasi Provinsi Jawa Timur. Retrieved from http://kominfo.jatimprov.go.id/read/umum/maret-2020-bps-jatim-catat-penduduk-miskin-dijatim-4-419-10-ribu-jiwa\#: : text=Jatim Newsroom - Badan Pusat Statistik,(11\%2C09 persen).

Kominfo. (2020b). Maret 2020, BPS Jatim Catat Penduduk Miskin di Jatim 4.419,10 Ribu Jiwa. Dinas Komunikasi Dan Informasi Provinsi Jawa Timur. Retrieved from http://kominfo.jatimprov.go.id/read/umum/maret-2020-bps-jatim-catat-penduduk-miskin-dijatim-4-419-10-ribu-jiwa\#: :text=Jatim Newsroom - Badan Pusat Statistik,(11\%2C09 persen).

Martianto, D., Riyadi, H., \& Ariefiani, R. (2011). Pola Asuh Makan Pada Rumah Tangga Yang Tahan Dan Tidak Tahan Pangan Serta Kaitannya Dengan Status Gizi Anak Balita Di Kabupaten Banjarnegara. Jurnal Gizi Dan Pangan, 6(1), 51. https://doi.org/10.25182/jgp.2011.6.1.51-58

Maxwell, D. (2000). Urban livelihoods and food and nutrition security in Greater Accra, Ghana. Retrieved

from https://books.google.com/books?hl=id\&lr=\&id=_zGFv43bPQgC\&oi=fnd\&pg=PR8\&dq=Maxwel I+D.,+C.+Levin,+M.A.+Klemeseau,+M.+Rull.,+S.+Morris+and+C.+Alandeke.+2000.+Urban+Li velihoods+and+Food+Nutrition+Security+in+Greater+Accra,+Ghana.+IFPRI+in+Collaborative +with+Noguchi+Memorial+for+Medical+Research+and+World+Health+Organization.+Resear c\&ots=isrcUvDyxv\&sig=okUMZ7dAWeGlcZquaGd2NY6RAo8

Mulyo, J. H., Sugiyarto, S., \& Widada, A. W. (2015). Dan Kemandirian Pangan Rumah Tangga Tani Daerah, Ketahanan Handoyo Mulyo, Jangkung Wahyu Widada, Arif Sosial Ekonomi Pertanian, Jurusan Pertanian, Fakultas Gadjah Mada, Universitas. Agro Ekonomi, 26(2), $121-$ 128. Retrieved from https://journal.ugm.ac.id/jae/article/view/17265

Purwaningsih, Y. (2008). Ketahanan pangan: situasi, permasalahan, kebijakan, dan pemberdayaan masyarakat. In Jurnal Ekonomi Pembangunan (Vol. 9). Retrieved from http://journals.ums.ac.id/index.php/JEP/article/view/1028 
Purwaningsih, Y., Hartono, S., \& Handoyo Mulyo, J. (2010). Pola Pengeluaran Pangan Rumah Tangga Menurut Tingkat Ketahanan Pangan Di Provinsi Jawa Tengah. In Jurnal Ekonomi $\begin{array}{llll}\text { Pembangunan (Vol. 11). } & \text { Retrieved }\end{array}$ http://journals.ums.ac.id/index.php/JEP/article/view/327

Purwaningsih, Y., Hartono, S., Masyhuri, M., \& Mulyo, J. H. (2010). Pola Pengeluaran Pangan Rumah Tangga Menurut Tingkat Ketahanan Pangan Di Provinsi Jawa Tengah. Jurnal Ekonomi Pembangunan: Kajian Masalah Ekonomi Dan Pembangunan, 11(2), 237. https://doi.org/10.23917/jep.v11i2.327

Puryantoro, P., \& Mayangsari, A. (2020). Pangsa Pengeluaran Pangan Rumah Tangga Kelompok Tani Mangga Di Kabupaten Situbondo. Prosiding Webinar Nasional Series Sistem Pertanian Terpadu Dalam Pemberdayaan Petani Di Era New Normal, 393-400. Retrieved from https://ppnp.ac.id/

Sari, A. K., Andrias, D. R., Bulak, K., \& Bulak, K. (2013). Faktor sosial ekonomi yang berhubungan dengan ketahanan pangan rumah tangga nelayan perkotaan di Surabaya. Media Gizi Indonesia, 9(1), 1.

Sinaga, R. J. R., Lubis, S. N., \& Darus, M. B. (2017a). Kajian faktor-faktor sosial ekonomi masyarakat terhadap ketahanan pangan rumah tangga di Medan. Journal of Agriculture and Agribusiness Socioeconomics, 2(5). Retrieved from https://media.neliti.com/media/publications/15067-IDkajian-faktor-faktor-sosial-ekonomi-masyarakat-terhadap-ketahanan-pangan-rumah-t.pdf

Sinaga, R. J. R., Lubis, S. N., \& Darus, M. B. (2017b). Kajian faktor-faktor sosial ekonomi masyarakat terhadap ketahanan pangan rumah tangga di Medan. In Journal of Agriculture and $\begin{array}{llll}\text { Agribusiness Socioeconomics (Vol. 2). Retrieved from } & \end{array}$ https://media.neliti.com/media/publications/15067-ID-kajian-faktor-faktor-sosial-ekonomimasyarakat-terhadap-ketahanan-pangan-rumah-t.pdf

Sugiarto, U., Karyani, T., \& Rochdiani, D. (2019). Pangsa Pengeluaran Pangan Rumah Tangga Petani Padi-Terpadu Di Kecamatan Pangkalan Kabupaten Karawang. Jurnal Agribinis Terpadu, 12(1), 25-35. Retrieved from http://jurnal.untirta.ac.id/index.php/jat/article/view/5532

Wahyuni, S., \& Fauzi, T. (2018). Prosiding Seminar Nasional Biotik 2016. Jurnal.Ar-Raniry.Ac.ld. Retrieved from https://jurnal.ar-raniry.ac.id/index.php/PBiotik/article/view/2578

Widayaningsih, N. (2012). Ketahanan Pangan Pada Rumah Tangga Miskin (Perbandingan Kasus di Perdesaan dan Perkotaan Kab. Banyumas). Pembangunan Pedesaan, 2(2), 45-55. Retrieved from http://jurnal.Ippm.unsoed.ac.id/ojs/index.php/Pembangunan/article/viewFile/212/211

Yuliana, P., Zakaria, W. A., \& Adawiyah, R. (2013). Ketahanan pangan rumah tangga nelayan di Kecamatan Teluk Betung Selatan Kota Bandar Lampung. JIIA, 1(2), 181-186. Retrieved from http://jurnal.fp.unila.ac.id/index.php/JIA/article/view/246 